\title{
PENGEMBANGAN PERANGKAT PRAKTIKUM BERORIENTASI LINGKUNGAN PENUNJANG PEMBELAJARAN IPA SMP SESUAI KURIKULUM 2013
}

\author{
I Dewa Putu Subamia', I.G.A.N.SriWahyuni², Ni Nyoman Widiasih ${ }^{3}$ \\ 1,2,3Universitas Pendidikan Ganesha \\ Singaraja, Indonesia \\ e-mail: ajiram_dewa@yahoo.com
}

\begin{abstract}
Abstrak
Penelitian ini bertujuan menghasilkan perangkat praktikum berorientasi lingkungan pada mata pelajaran IPA SMP sesuai kurikulum 2013. Penelitian ini merupakan penelitian pengembangan yang mengacu pada model pengembangan oleh Borg dan Gall, yang dapat dibagi menjadi tiga tahap, yaitu: studi pendahuluan, studi pengembangan, dan uji produk. Data yang dikumpulkan berupa data kualitatif dan kuantitatif menggunakan angket.Subjek pada penelitian ini adalah ahli, guru, dan siswa. Guru dan siswa yang dijadikan sampel pada uji coba adalah guru IPA dan siswa SMPN 2 Singaraja. Hasil pengujian menunjukkan bahwa perangkat praktikum yang dikembangkan termasuk kriteria valid. Skor rata-rata uji keterbacaan pada uji coba terbatas termasuk kriteria sangat valid. Pada uji coba terbatas dan luas hampir seluruh siswa memberi respon positif terhadap pemanfaatan perangkat praktikum yang dikembangkan. Guru memberi respon positif terhadap perangkat praktikum berorientasi lingkungan, baik dari segi kemudahan mempersiapkan maupun mengimplementasikannya. Disimpulkan bahwa perangkat praktikum berorientasi lingkungan yang dikembangkan sudah memenuhi kriteria relevan dan mudah digunakan.
\end{abstract}

Kata kunci: berorientasi lingkungan, perangkat praktikum.

\begin{abstract}
This study aims to produce practical tools oriented environment in science subjects in accordance curriculum SMP 2013. This study is a development which refers to the model of development by Borg and Gall, which can be divided into three stages: preliminary studies, development studies, and product test, The data collected in the form of qualitative and quantitative data used in this study is angket.Subjek experts, teachers, and students. Teachers and students were sampled at the trial was a science teacher and a student of SMPN 2 Singaraja. The test results showed that the lab developed tools including valid criteria. The average score on a test of legibility limited trial included a very valid criteria. In the limited testing and the area nearly all of the students responded positively to the use of practical tools developed. Teacher gives a positive response to the device-oriented lab environment, both in terms of ease of preparing and implementing them. It was concluded that the device is oriented lab environment that was developed has met the relevant criteria and easy to use.
\end{abstract}

Keywords: development, practicaldevices, orientedenvironment

\section{PENDAHULUAN}

Kurikulum 2013 menekankan pada dimensi pedagogik modern dalam pembelajaran, yaitu menggunakan pendekatan ilmiah (scientific appoach). Pendekatan ilmiah dalam pembelajaran sebagaimana dimaksud meliputi mengamati, menanya, menalar, mencoba, dan membentuk jejaring. Proses pembelajaran menyentuh tiga ranah, yaitu sikap, pengetahuan, dan keterampilan. Pembelajaran yang diupayakan harusnya pembelajaran berbasis aktivitas (Kemendikbud. 2013). Oleh karenanya, pembelajaran yang relevan digunakan adalah pembelajaran yang didukung oleh kegiatan laboratorium (praktikum).

Salah satu kompetensi inti mata pelajaran IImu Pengetahuan Alam (IPA) 
dalam kurikulum 2013 adalah memahami dan menerapkan pengetahuan (faktual, konseptual, dan prosedural) berdasarkan rasa ingin tahu tentang ilmu pengetahuan, teknologi, seni, budaya terkait fenomena dan kejadian tampak mata. Pembelajaran yang paling tepat diterapkan adalah pembelajaran melalui eksperimen (Kemendikbud. 2013). Dengan demikian, sebagai penunjang pembelajaran untuk mencapai tujuan kurikulum 2013 (khususnya pada pembelajaran IPA), keberadaan perangkat laboratorium menjadi sangat penting.

Kegiatan laboratorium memberi peran yang sangat besar terutama dalam membangun pemahaman konsep, verifikasi (pembuktian) kebenaran konsep, menumbuhkan keterampilan proses (keterampilan dasar bekerja ilmiah dan kemampuan afektif siswa), dan menumbuhkan "rasa suka" terhadap pelajaran IPA (Koretsky, et.al., 2011). Di samping melatih keterampilan, kegiatan laboratorium juga berperan dalam melatih dan mengembangkan nilai-nilai sikap ilmiah, seperti: kritis, objektif, kreatif, skeptis, terbuka, disiplin, tekun, mengakui kelebihan orang lain, dan kekurangan diri sendiri (Academy Savant, eLearning Science. 2012). Oleh karena itu, optimalisasi dan efektivitas pemanfaatan laboratorium harus diupayakan sebaik-baiknya.

Dalam

penyampaian

pembelajaran IPA, diperlukan suatu sarana yang berupa model pembelajaran beserta perangkat pembelajaran yang sesuai (Rahayu, 2012). Untuk menunjang kegiatan praktikum dalam pembelajaran IPA, tentu dibutuhkan perangkat praktikum yang sesuai pula. Berkaitan dengan itu Munandar (2008:10) mengatakan bahwa "kegiatan belajar mengajar IPA hendaknya diberikan melalui menyentuh benda-benda yang nyata". Dengan demikian mungkin saja diantara para siswa banyak yang sudah mengenal alat-alat yang dipakai mengadakan percobaan oleh gurunya dalam kehidupan sehari-hari. $\mathrm{Hal}$ ini menyebabkan pusat perhatian siswa menjadi lebih terpusat pada obyek yang diajarkan dan bukan terpesona. Para siswa akan tertarik bukan pada obyek yang dijelaskan melainkan tertarik pada alat itu sendiri. Pemahaman terhadap konsep-konsep IPA, terlebih dahulu diawali dengan melihat dan menjalani dengan dasar bahwa segala pikiran berawal dari pengamatan dan pada akhirnya mengerti. Oleh karena itu, kegiatan belajar mengajar IPA hendaknya melalui kegiatan praktikum untuk mengerjakan suatu percobaan diperlukan alat KIT IPA yang mendukung percobaan (Dian, $P$ et.al 2013). Praktikum diharapkan dapat membantu peserta didik membangun pemahaman konsep-konsep IPA secara utuh. Perangkat praktikum memuat petunjuk praktikum, alat/bahan keperluan praktikum, dan prosedur praktikum yang dapat membantu siswa menemukan konsep-konsep IPA. Dengan perangkat praktikum IPA yang sesuai, diharapkan kegiatan pembelajaran menjadi lebih baik, efektif, dan lebih membantu siswa membangun keutuhan makna dari konsep-konsep IPA yang dibelajarkan. Implikasinya adalah tujuan pembelajaran dapat dicapai dengan lebih bermakna.

Namun kenyataan, berdasarkan hasil pengamatan dan penelitian di lapangan, praktikum justru jarang dilakukan dalam pembelajaran IPA di SMPN 2 Singaraja. Hal ini disebabkan oleh beberapa faktor, antara lain: umumnya praktikum memerlukan sarana dan biaya yang relatif mahal dan membutuhkan banyak waktu. Kondisi fasilitas sarana dan prasarana laboratorium khususnya pada pembelajaran IPA di SMPN 2 Singaraja relatif tidak memadai. Fakta-fakta lain yang dijumpai di lapangan antara lain: (1) fasilitas, alat, dan bahan praktikum yang ada jika dibandingkan dengan rasio jumlah peserta didik pemakai laboratorium masih sangat minimum, (2) laboratorium kurang difungsikan secara optimal sebagai tempat melaksanakan eksperimen, bahkan ada ruang laboratorium dialihfungsikan sebagai ruang kelas, dan (3) tidak adanya 
tenaga laboran yang khusus bertugas secara rutin menyiapkan alat dan bahan yang dibutuhkan oleh guru IPA untuk kegiatan praktikum (Subamia, dkk., 2012). Kondisi tersebut menunjukkan bahwa sejauh ini laboratorium IPA di SMP belum sesuai dengan harapan kurikulum 2013.

Di sisi lain, penerapan IPA perlu dilakukan secara bijaksana untuk menjaga dan memelihara kelestarian lingkungan. Hal ini mengisyaratkan bahwa dalam kegiatan pembelajaran IPA di samping mengupayakan pembelajaran berkualitas, keselamatan dan kelestarian lingkungan hendaknya senantiasa diperhatikan. Oleh karena itu, untuk menjaga kelangsungan pendidikan IPA melalui praktikum perlu dikembangkan alternatif perangkat praktikum IPA agar pembelajaran IPA dapat berjalan secara baik serta tetap memperhatikan aspek lingkungan.

Berdasarkan identifikasi masalah yang dipaparkan di depan, permasalahan dalam penelitian ini adalah sebagai berikut. (a) Bagaimana mengembangkan perangkat praktikum IPA berorientasi lingkungan dalam pembelajaran IPA SMP sesuai kurikulum 2013? (b) Apakah pengembangan perangkat praktikum IPA berorientasi lingkungan sebagai penunjang pembelajaran IPA efektif meningkatkan kualitas pembelajaran IPA di SMPN 2 Singaraja?

Tujuan penelitian ini adalah mengembangkan perangkat KIT IPA penunjang praktikum alternatif yang relatif lebih murah dan mudah untuk mengatasi permasalahan keterbatasan sarana dan prasarana laboratorium sebagai penunjang pembelajaran IPA di SMP sesuai kurikulum 2013. Secara spesifik tujuan penelitian ini adalah (a) menganalisis topik-topik esensial praktikum IPA SMP, (b) mengidentifikasi potensi lingkungan yang relevan sebagai bahan/alat pengembangan perangkat praktikum sesuai konsep kunci dan struktur konsep IPA dalam kurikulum 2013, (c) menghasilkan KIT IPA berorientasi lingkungan penunjang praktikum dalam menunjang pembelajaran IPA SMP sesuai kurikulum 2013, dan (d) mengetahui respon siswa terhadap pemanfaatan perangkat praktikum IPA berorientasi lingkungan sebagai penunjang pembelajaran IPA sesuai kurikulum 2013 di kelas VII SMP N 2 Singaraja.

\section{METODE}

Penelitian dilakukan menggunakan desain research and development. Prosedur pengembangan perangkat praktikum IPA mengacu pada model penelitian pengembangan dari Borg dan Gall (1983), yang terdiri atas 3 tahap, yaitu: tahap studi pendahuluan, studi pengembangan, dan uji produk.

\section{Tahap I: Studi Literatur dan Observasi Sekolah}

Tahap ini merupakan tahap pertama atau persiapan untuk pengembangan.Tahap ini terdiri atas studi pustaka dan survei lapangan. Studi pustaka dilakukan untuk mengumpulkan berbagai informasi terhadap kebutuhan yang berhubungan dengan pengembangan produk berupa perangkat praktikum yang akan dihasilkan sesuai dengan Kurikulum 2013. Survei lapangan dilakukan dengan tujuan memperoleh informasi tentang kondisi dan fakta pembelajaran IPA di lapangan. Informasi-informasi minimum yang harus didapatkan pada tahap penelitian ini adalah antara lain masalah-masalah yang timbul pada pembelajaran IPA, di antaranya optimalisasi pembelajaran IPA dalam keterlaksanaan praktikum di sekolah.

\section{Tahap II : Perancangan}

Tahap ini merupakan prosedur untuk menentukan isi satuan pelajaran. Analisis tugas dilakukan dengan merinci tugas isi bahan ajar dalam bentuk garis besar. Hal ini mencakup analisis struktur isi dan penyusunan draf: 1) Analisis struktur isi berdasarkan kurikulum 2013 di SMP dengan topik "Perubahan Benda-benda di Sekitar" dianalisis dan diperoleh hasil sebagai berikut: Kompetensi Dasar, a) Menunjukkan prilaku ilmiah (memiliki rasa ingin tahu, objektif, jujur, teliti, cermat, tekun, hatihati, bertanggung jawab, terbuka, kritis, 
kreatif, inovatif dan peduli lingkungan) dalam aktivitas sehari-hari; b) Menghargai kerja individu dan kelompok dalam aktivitas sehari-hari sebagai wujud implementasi melaksanakan percobaan dan melaporkan hasil percobaan; c) Menunjukkan perilaku bijaksana dan bertanggungjawab dalam aktivitas sehari-hari; d) Memahami karakteristik zat, serta perubahan fisika dan kimia pada zat yang dapat dimanfaatkan untuk kehidupan seharihari; e) Melakukan pemisahan campuran berdasarkan sifat fisika dan kimia zat. 2) Penyusunan Draf, Adapun format yang akan digunakan dalam penelitian pengembangan perangkat pembelajaran ini meliputi: a) Silabus; b) Rencana Pelaksanaan Pembelajaran (RPP); c) Buku panduan peserta didik; d) Lembar Kegiatan Siswa (LKS). Penyusunan LKS dilakukan dengan pendekatan eksperimen dengan mengadaptasi buku panduan siswa.

\section{Tahap III Pengembangan}

Draf I merupakan perangkat praktikum berorientasi lingkungan pada mata pelajaran IPA yang terdiri atas silabus, RPP IPA, pedoman bagi siswa, Lembar Kerja Siswa (LKS): a) Revisi I. Revisi I dilakukan berdasarkan hasil penilaian kelayakan ahli, Guru IPA, dan teman sejawat pada Draft I sehingga menghasilkan Draft II; b) Uji Coba Terbatas. Tahap uji coba terbatas dilakukan dengan menggunakan Draf II dan diamati dengan menggunakan lembar keterlaksanaan pembelajaran yang mengacu pada RPP yang telah dikembangkan. Berbagai data dan masukan yang diperoleh dalam uji coba ini dijadikan sebagai bahan revisi dan perbaikan; c) Revisi II. Revisi II dilakukan berdasarkan hasil ujicoba terbatas sehingga menghasilkan Draf III; d) Uji Coba Lapangan. Tahap uji coba lebih luas dilakukan dengan menggunakan Draf III. Uji coba ini bertujuan melihat kevalidan dan keefektifan perangkat praktikum berorientasi lingkungan dalam meningkatkan hasil belajar IPA siswa. Berbagai data dan masukan yang diperoleh pada uji coba ini dijadikan sebagai bahan revisi dan perbaikan; e) Revisi III. Revisi III dilakukan berdasarkan hasil yang diperoleh dari uji coba lapangan. Setelah revisi dan penyempurnaan dilakukan, maka akan diperoleh perangkat praktikum berorientasi lingkungan.

\section{Uji coba Produk}

Desain Uji coba produk yang dilakukan bertujuan menyempurnakan perangkat praktikum dengan mengimplementasikan secara langsung di lapangan. Ujicoba yang dilakukan adalah sebagai berikut: a) Uji ahli dan praktisi. Uji ahli dan praktisi dilakukan oleh ahli pembelajaran IPA dan guru yang berpengalaman untuk menilai dan memberikan masukan terhadap produk awal. Uji ahli dan praktisi ini untuk memvalidasi produk sebelum diujicobakan di lapangan; b) Uji coba terbatas. Uji coba terbatas hanya mengambil satu kelas, yaitu kelas VIIA SMP. Uji coba ini bertujuan menentukan keefektifan perubahan yang telah dibuat menyusul dilangsungkannya uji coba ahli perangkat dan mengenali masalahmasalah yang mungkin dialami oleh siswa. Prosedur pokok yang digunakan dalam penilaian kelompok kecil dilakukan dengan cara interaksi secara langsung dengan siswa; c) Uji coba luas. Uji coba luas diterapkan pada 2 kelas dari sekolah yang berbeda. Pada tahap ini dilakukan pembelajaran dan observasi. Kegiatan yang dilakukan hampir mirip dengan kegiatan yang dilakukan pada uji coba terbatas. Perbedaannya, subjek uji coba skala luas lebih banyak daripada uji coba terbatas. Maksud tahap ini untuk menentukan efektivitas perubahanperubahan yang telah dilakukan danmenguji kelayakan perangkat tersebut dierapkan pada lingkungan yang dimaksudkan.

\section{Variabel yang Diamati/Diukur}

Subjek dalam penelitian ini adalah ahli, siswa dan guru. Ahli adalah seorang profesor dan seorang doktor yang memiliki keahlian di bidang pendidikan IPA serta media (alat peraga IPA), berperan untuk memvaliditas 
perangkat praktikum (LKS dan KIT IPA). Siswa dan guru berperan dalam memperoleh data tentang kepraktisan dan efektivitas perangkat pembelajaran. Siswa yang dimaksud adalah siswa kelas VIIA dan kelas VIIB SMP Negeri 2 Singaraja tahun pelajaran 2014/2015. Sebagai objek atau peubah yang diukur dalam penelitian adalah aspek-aspek pendukung perangkat praktikum, meliputi: RPP, LKS, KIT Alat Praktikum IPA berorientasi lingkungan dan pedoman penggunaan KIT IPA.

\section{Lokasi penelitian}

Tempat yang dipilih dalam penelitian ini adalah SMP Negeri 2 Singaraja. Sekolah ini merupakan salah satu sekolah yang ditunjuk sebagai salah satu pilot projek pelaksanaan kurikulum 2013. Waktu penelitian adalah pada semester ganjil tahun pelajaran 2014/2015.

\section{Jenis Data}

Data yang diperoleh pada penelitian ini merupakan data primer. Data ini berkaitan dengan validasi dan tanggapan dari ahli, guru, teman sejawat, dan siswa tentang perangkat praktikum berorientasi lingkungan yang dikembangkan. Pada setiap uji coba juga diperoleh data keterlaksanaan pembelajaran dengan menggunakan perangkat praktikum berorientasi lingkungan hasil pengembangan. Selain itu, data angket dan observasi keterampilan proses dan sikap ilmiah peserta didik serta kemampuan awal dan hasil belajar sains peserta didik juga diperoleh pada penelitian ini.

\section{Instrumen Pengumpulan Data}

Instrumen yang digunakan pada penelitian ini adalah (1) lembar validasi perangkat pembelajaran, (2) angket respon guru dan (3) angket respon siswa.

\section{Analisis Data}

Data yang dikumpulkan berupa data kualitatif dan kuantitatif melalui instrumen angket.Data hasil uji validasi dianalisis dengan teknik analisis ratarata, selanjutnya produk direvisi sesuai hasil analisis data dan saran dari validator. Analisa data tiap komponen baik hasil penilaian ahli, uji coba terbatas, uji coba luas, maupun uji coba lapangan dilakukan secara deskriptif, yaitu berupa rerata dan persentase. Persentase tingkat pencapaian dihitung dengan menggunakan rumus:

$$
=\frac{\sum(\text { jawaban } \times \text { bobot tiap pilihan })}{n \times \text { bobot terting })} \times 100 \%
$$

Tabel 1. Pedoman konversi tingkat pencapaian

\begin{tabular}{cll}
\hline \multicolumn{1}{c}{ No. } & \multicolumn{1}{c}{ Kriteria } & \multicolumn{1}{c}{ Kualifikasi } \\
\hline 1 & $>\left(M_{i}+1,5 S D_{i}\right)$ & Sangat baik \\
2 & $\left(M_{i}+0,5 S D_{i}\right)-\left(M_{i}+1,5 S D_{i}\right)$ & Baik \\
3 & $\left(M_{i}-0,5 S D_{i}\right)-\left(M_{i}+0,5 S D_{i}\right)$ & Sedang \\
4 & $\left(M_{i}-1,5 S D_{i}\right)-\left(M_{i}+0,5 S D_{i}\right)$ & Kurang \\
5 & $<\left(M_{i}-1,5 S D_{i}\right)$ & Sangat Kurang \\
\hline
\end{tabular}

\section{HASIL DAN PEMBAHASAN}

Hasil penelitian pengembangan ini berupa prototype perangkat penunjang praktikum pada pembelajaran IPA SMP, berupa petunjuk praktikum (lembar kerja siswa), KIT IPA berorientasi lingkungan, dan lembar penilaian kinerja praktikum. Berikut disajikan gambar (foto) model

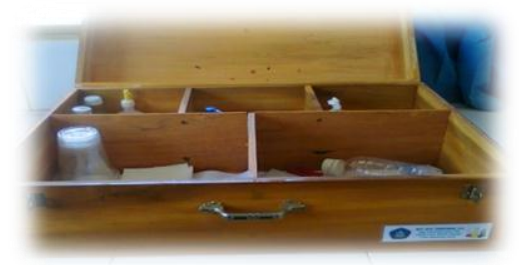

Gambar 2. Model KIT IPA KIT praktikum IPA yang dikembangkan. 


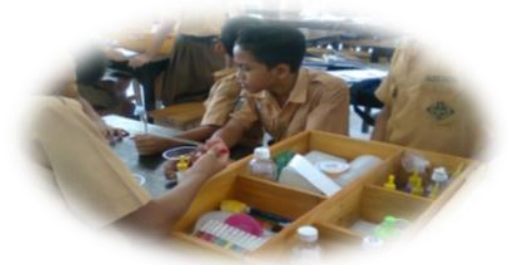

\section{Gambar 3. Pemanfaatan KIT IPA}

KIT IPA ini dikemas dalam kemasan kotak yang terbuat dari kayu dan triplek. Dalam kotak KIT berisi alat dan sekaligus bahan yang dibutuhkan untuk kegiatan praktikum sesuai petunjuk praktikum (LKS). Alat dan bahan yang dipakai sebagian besar dengan pemanfaatan barang-barang bekas dan bahan-bahan yang mudah didapat dari lingkungan sekitar. Misalnya, untuk mengganti alat-alat gelas dipakai gelas bekas air minuman mineral, pembakar spiritus dibuat dari botol bekas minuman suplemen, untuk alat ukur dimanfaatkan spite bekas injector tinta printer reftil, pengganti tabung reaksi dimanfaatkan botol bening kecil bekas tempat parfum. Demikian pula bahan-bahan yang dirujuk dalam petunjuk praktikum (LKS), memanfaatkan bahan-bahan yang mudah diperoleh dari lingkungan sekitar. Misalnya, untuk bahan indikator memanfaatkan bahan-bahan alam seperti kunir, bunga kol, kembang ungu, dll. Untuk pengenalan larutan asam, basa dan garam menggunakan asam alami (cuka, ekstrak buah jeruk), larutan basa (kapur tohor, batu kapur, abu, dII).Garam, menggunakan garam dapur, air laut, dll.

Perangkat praktikum yang dikembangkan memiliki kelebihan dengan perangkat praktikum standar, antara lain: 1) perangkat praktikum ini disesuaikan dengan kurikulum 2013 yang menuntut pembelajaran IPA SMP dilakukan dengan pendekatan ilmiah (scientific approach); 2) konten materi praktikumnya terintegrasi, diupayakan sesuai dengan konten IPA terpadu; 3) perangkat praktikum ini merujuk bahan/alat yang dekat dan mudah diperoleh dari lingkungan sekitar; 4) memberikan kemudahan bagi siswa untuk melakukan kegiatan, karena petunjuk praktikum (LKS) diadaptasi dari petunjuk percobaan (kegiatan) yang sudah tercantum pada buku siswa; 5) memberikan kemudahan bagi guru dalam melaksanakan proses pembelajaran dengan eksperimen karena perangkat penunjang praktikum telah tersusun dengan rapi dalam satu kotak kemasan (KIT IPA) dan dilengkapi instruksi kerja alat.

Hasil pengujian menunjukkan bahwa skor rata-rata uji validasi isi terhadap produk petunjuk praktikum, perangkat KIT IPA dan lembar penilaian kinerja praktikum berturut-turut sebesar 3,07, 3,22 dan 3,44 serta termasuk kategori valid. Selain itu, skor rata-rata uji keterbacaan terbatas terhadap petunjuk praktikum dan penilaian kinerja praktikum berorientasi lingkungan berturut-turut 3,37 dan 3,38 serta termasuk kategori sangat valid. Hasil validasi konten dan konstruk oleh ahli dan guru terhadap petunjuk praktikum (LKS) berturut-turut adalah $94,30 \%$ dan $89,55 \%$. Hasil ini termasuk valid.

Berdasarkan hasil pengujian tersebut, model KIT IPA berorientasi lingkungan yang dikembangkan sudah memenuhi kriteria relevan atau baik. Hasil penilaian ahli juga menyatakan kelebihan KIT IPA ini adalah (1) bahan dan alat yang dirujuk/digunakan adalah bahan/alat pengganti (suplemen) yang bisa diperoleh dengan mudah dari lingkungan sekitar, (2) praktis dan mudah digunakan pada kegiatan praktikum, (3) dapat menunjang kebutuhan pembelajaran dengan pendekatan ilmiah (scientific approach), dan (4) pendekatan yang diacu juga adalah pendekatan kontekstual yang mengaitkan pembelajaran dengan konteks kehidupan sehari-hari peserta didik (relevan dengan tuntutan kurikulum 2013). Sementara itu, kekurangan KIT IPA ini adalah (1) belum mencakup materi IPA terpadu, (2) petunjuk perlu dibuat lebih terstruktur agar memberi tuntunan secara mudah dan cepat kepada siswa, dan (3) perlu dilengkapi soal-soal pendalaman untuk mengeksplorasi pemahaman siswa terhadap konsep-konsep yang dibelajarkan. 
Hasil ujicoba terbatas menunjukkan bahwa guru menilai pemanfaatan perangkat KIT IPA dalam praktikum sangat layak. Siswa menunjukkan respon positif pada ujicoba terbatas (96,3\%). Aktivitas siswa termasuk kategori aktif dan sangat aktif dalam pembelajaran di kelas ujicoba terbatas $(93,3 \%)$. Dari hasil tersebut, petunjuk praktikum (LKS) yang dikembangkan sudah memenuhi kriteria valid atau baik.

Tahap berikutnya dilakukan ujicoba luas dengan membandingkan respon siswa terhadap pembelajaran IPA tanpa menggunakan KIT IPA berorientasi lingkungan. Hasil penilaian oleh siswa terhadap pemanfaatan produk pada skala luas termasuk kategori baik. Respon siswa pada pembelajaran yang memanfaatkan perangkat praktikum berorientasi lingkungan lebih baik dan lebih menyenangkan daripada respon siswa pada pembelajaran konvensional (tanpa menggunakan KIT IPA). Siswa menunjukkan respon positif pada ujicoba luas (skor rata-rata 96,6\%). Dari hasil pengamatan terhadap aktivitas siswa, pada pembelajaran memanfaatkan perangkat praktikum berorientasi lingkungan siswa lebih aktif dibandingkan pada pembelajaran tanpa perangkat praktikum. Aktivitas siswa terhadap pemanfaatan perangkat praktikum berorientasi lingkungan dalam pembelajaran IPA termasuk sangat positif (96,8\%). Hal tersebut menunjukkan bahwa perangkat praktikum yang dikembangkan mampu mendukung proses pembelajaran IPA menjadi lebih menarik.

Guru memberi respon positif terhadap perangkat praktikum IPA berorientasi lingkungan, baik dari kemudahan mempersiapkan maupun dari kemudahan mengimplementasikannya. Dari hasil tersebut, dapat disimpulkan bahwa model perangkat praktikum berorientasi lingkungan yang dikembangkan sudah memenuhi kriteria relevan dan mudah digunakan. Respon siswa terhadap pemanfaatan perangkat praktikum berorientasi lingkungan dalam pembelajaran IPA diperoleh hasil, yaitu: jumlah siswa yang memberikan respon positif sebesar $87,8 \%$ dan memberi respon sangat positif sebesar $7,3 \%$. Jumlah siswa yang memberi respon posistif dan sangat positif adalah $95,1 \%$. Hal tersebut menunjukkan bahwa perangkat praktikum mampu mendukung proses pembelajaran IPA menjadi lebih menarik. Hasil wawancara dengan guru menunjukkan bahwa guru memberi kesan positif terhadap perangkat praktikum berorientasi lingkungan, baik dari mudahnya mempersiapkan maupun dari mudahnya mengaplikasikannya.

Dalam hal respon siswa terhadap pemanfaatan perangkat praktikum IPA berorientasi lingkungan dalam pembelajaran IPA diperoleh hasil jumlah siswa yang mempunyai respon positif mencapai 36 siswa dari 41 orang atau $87,8 \%$ dan 3 orang $(7,1 \%)$ memberi respon sangat positif. Hal tersebut menunjukkan perangkat praktikum IPA mampu mendukung proses pembelajaran IPA menjadi lebih menarik. Ketertarikan siswa dimungkinkan karena pembelajaran IPA berbantuan KIT IPA berorientasi lingkungan secara tidak langsung menuntut siswa aktif melakukan sendiri dan menemukan sendiri.Hal ini ini juga dapat diamati dari semangat dan aktivitas siswa dalam pembelajaran. Karli dan Margaretha (2002) menjelaskan bahwa pendekatan lingkungan adalah suatu strategi pembelajaran yang memanfaatkan lingkungan sebagai sasaran belajar, sumber belajar, dan sarana belajar. Hal tersebut dapat dimanfaatkan untuk menarik minat siswa, dan untuk menanamkan sikap cinta lingkungan.

Perangkat praktikum IPA membutuhkan alat dan bahan untuk mendukung kegitan praktikum yang dikemas dalam kotak unit pembelajaran. Perangkat ini menyerupai rangkaian peralatan uji coba keterampilan proses pada bidang studi IPA dan dilengkapi dengan buku pedoman penggunaannya. Shadely (dalam Suharningrum, 2010) berpendapat bahwa alat perga KIT IPA adalah kotak yang berisi alat-alat IPA. Seperangkat peralatan IPA tersebut 
mengarah pada kegiatan yang berkesinambungan atau berkelanjutan. Peralatan IPA yang dirancang dan dibuat ini menyerupai rangkaian peralatan uji coba keterampilan proses pada bidang studi IPA. Sebagai alat yang dirancang dan dibuat secara khusus ini, maka dapat diartikan bahwa "alat peraga" KIT IPA merupakan suatu sistem yang didesain atau dirancang secara khusus untuk suatu tujuan tertentu (Suharningrum, 2010).

$$
\text { Laboratorium dan jenis }
$$

peralatannya merupakan sarana dan prasana penting untuk penunjang proses pembelajaran di sekolah. Peraturan Pemerintah Republik Indonesia Nomor 19 Tahun 2005 tentang Standar Nasional Pendidikan Pasal 42 ayat (2), Pasal 43 ayat (1) dan ayat (2) mensyaratkan bahwa pendidikan wajib memiliki prasarana termasuk ruang laboratorium untuk menunjang proses pembelajaran yang teratur dan berkelanjutan. Lebih jauh dijelaskan bahwa untuk meningkatkan efesiensi dan efektivitas, laboratorium harus dikelola dan dimanfaatkan dengan baik. Tujuan pembelajaran IPA di SMP hanya dapat dicapai secara optimal bila guru menggunakan laboratorium sebagai sarana dan prasarana belajar siswa (Sulastri, 2008).

Pada pembelajaran yang memanfaatkan perangkat praktikum IPA berorientasi lingkungan, siswa dilibatkan dalam aktivitas penting yang membantu mereka mengaitkan pelajaran akademis dengan konteks kehidupan nyata yang mereka hadapi sehingga pembelajaran menjadi lebih bermakna bagi siswa. Hal ini sesuai dengan hakikat pembelajaran kontekstual, yaitu: makna, bermakna, dan dibermaknakan.

$$
\text { Johnson, E.B. (2002) }
$$

menyebutkan bahwa pembelajaran kontekstual (contextual teaching and learning) adalah sistem pembelajaran yang didasarkan pada filosofi bahwa siswa belajar bila mereka memperoleh makna dalam materi pelajaran yang dipelajari dan bisa menghubungkan informasi yang baru diperoleh dengan pengetahuan awal yang dimiliki dan pengalaman mereka (Johnson, E.B.
2002). Dengan melibatkan siswa secara langsung dan mengaitkan materi pelajaran dengan lingkungan sekitarnya diharapkan proses pembelajaran akan berlangsung lebih bermakna. Menurut Yulianto (2002) pendekatan lingkungan berarti mengaitkan lingkungan dalam suatu proses belajar mengajar dimana lingkungan digunakan sebagai sumber belajar. Penggunaaan lingkungan memungkinkan terjadinya proses belajar yang lebih bermakna sebab anak dihadapkan pada kondisi yang sebenarnya.

Setiap pembelajaran selalu diamati proses belajar dan mengajar yang terjadi, dicatat dalam lembar observasi aktivitas siswa. Dari hasil pengamatan pembelajaran, ternyata siswa yang dibelajarkan dengan perangkat praktikum IPA lebih aktif dibandingkan dengan siswa yang dibelajarkan tanpa praktikum. Hasil pengamatan menunjukkan bahwa aktivitas siswa termasuk kriteria aktif dan sangat aktif. Dengan demikian, pembelajaran IPA yang memanfaatkan KIT IPA mampu meningkatkan aktivitas dan efektivitas pembelajaran IPA. Hal ini dapat dijelaskan bahwa pembelajaran menggunakan perangkat praktikum IPA merupakan pembelajaran yang berorientasi pada keterampilan proses. Implementasi pembelajaran menggunakan perangkat praktikum IPA memberi ruang seluas-luasnya bagi siswa untuk membangun konsep sains melalui pengalaman langsung. Model pembelajaran menggunakan praktikum memiliki karakter yang relevan dengan karakter materi pelajaran sains. Memperhatikan kesesuaian antara tuntutan materi, karakteristik IPA, dan tuntutan tujuan pembelajaran, dapat disimpulkan bahwa pembelajaran praktikum menggunakan perangkat praktikum IPA sangat relevan diterapkan pada pembelajaran IPA.

Hal penting yang perlu diperhatikan pada pembelajaran menggunakan praktikum berbatuan KIT IPA adalah pembelajaran berpusat pada siswa (student-centered). Aktivitas pembelajaran lebih banyak memberi peluang kepada siswa untuk 
mengaktualisasi kreativitas berpikir dengan melakukan eksperimen secara langsung. Pembelajaran sains dilaksanakan dengan pendekatan ilmiah (scientific approach) sehingga mampu menumbuhkan kemampuan berpikir, bekerja dan bersikap ilmiah serta mengomunikasikannya sebagai aspek penting kecakapan hidup. Keterampilan proses sains menjamin siswa memperoleh pengalaman belajar yang bermakna sebab hal ini membantu siswa mengembangkan keterampilan berpikir tingkat tinggi, seperti berpikir kritis, membuat keputusan, dan pemecahan masalah (Karsli \& Sahin, 2009).

Pembelajaran IPA dengan model pembelajaran menggunakan praktikum berbantuan KIT praktikum berorientasi lingkungan dapat memfasilitasi siswa memperoleh keterampilan-keterampilan, memelihara sikap-sikap, dan mengembangkan pemahaman konsep-konsep yang berkaitan dengan pengalaman seharihari. Perangkat praktikum ini menyajikan materi yang dekat dengan dunia siswa, artinya bahan-bahan yang dipergunakan sudah dikenal dan mudah didapat dari lingkungan sekitar. Secara tidak langsung akan membantu siswa memahami dan mencintai lingkungan. Pembelajaran ini juga memberi ruang bagi siswa untuk melakukan discovery. Hal ini sesuai dengan pendekatan yang ditekankan dalam kurikulum 2013.

Begitu halnya dengan hasil wawancara dengan guru bahwa guru memberi kesan positif terhadap perangkat praktikum IPA berorientasi lingkungan, baik dari mudahnya mempersiapkan, maupun mudahnya mengaplikasikannya. Mudah mempersiapkan maupun menggunakan karena perangkat alat dan petunjuk praktikum yang dibutuhkan telah dikemas dalam satu KIT perangkat praktikum yang siap digunakan. Sehingga pada waktu akan dipergunakan, guru cukup hanya miminta kepada masing-masing perwakilan siswa untuk mengambil KIT tersebut. Di samping itu bahan/alat pengganti untuk keperluan praktikum juga dengan mudah bisa didapatkan dari lingkungan sekitar.

Penyediaan perangkat penunjang praktikum berupa KIT IPA dapat membantu guru dalam melaksanakan kegiatan praktikum. Guru tidak terbebani untuk menyiapkan persiapan praktikum. Di samping itu juga dapat mengatasi masalahtidak adanya tenaga khusus di laboratorium (laboran) yang seharusnya menangani persiapan di laboratorium dan tidak sesuainya alat/bahan yang tersedia di laboratorium dengan kebutuhan praktikum.

Namun meskipun demikian, ada dua hal yang perlu disadari oleh guru. Pertama, guru mesti menyadari bahwa IPA merupakan ilmu berbasis eksperimen. Sejalan dengan itu, laboratorium dan praktikum tidak hanya merupakan pendukung pembelajaran IPA, tetapi menjadi bagian dari sistem akademik pembelajaran IPA. Kedua, guru mesti melakukan redefinisi terhadap pembelajaran IPA, yang tidak lagi berorientasi pada banyaknya materi yang mesti diinformasikan, tetapi menekankan kompetensi yang harus dikuasi siswa. Atas dasar itu, guru mesti memilah dan memilih materi yang esensial diajarkan kepada siswa agar mereka menguasai kompetensi sesuai tuntutan kurikulum.

\section{SIMPULAN DAN SARAN}

Dari hasil analisis data dan pembahasan yang telah dipaparkan di atas, dapat disimpulkan bahwa pengembangan perangkat penunjang praktikum berorientasi lingkungan yang berupa penuntun praktikum (LKS) dan KIT IPA mencapai kriteria valid dengan kategori sangat baik sehingga dapat digunakan tanpa revisi. Implementasi pemanfaatan perangkat penunjang praktikum dalam pembelajaran IPA di SMPN 2 Singaraja mencapai kriteria efektif.Siswa memberi respon positif terhadap pemanfaatan perangkat penunjang praktikum dalam pembelajaran IPA. Guru juga memberi respon positif terhadap penerapan perangkat praktikum berorientasi lingkungan. Penyediaan perangkat 
penunjang praktikum berupa KIT IPA dirasa sangat mendukung dan memudahkan guru dalam penyiapan perangkat kegiatan praktikum dalam pembelajaran IPA.

Untuk mengatasi kendala/hambatan yang dihadapi sekolah dalam pembelajaran IPA dengan pendekatan eksperimen (praktikum), dapat disarankan sebagai berikut: 1) Untuk menanggulangi keterbatasan alat/bahan praktikum, perlu ada perhatian lebih sungguh-sungguh dari pihak pengelola laboratorium maupun kepala sekolah dalam hal penyesuaian alokasi dana anggaran pengadaan sarana kegiatan praktikum. Realisasi program-program untuk meningkatkan efektifitas dan optimalisasi pemanfaatan laboratorium dalam pembelajaran IPA; 2) Bagi guru IPA disarankan untuk menumbuhkan kemauan dan kemampuan kreatif mengembangkan perangkat penunjang praktikum, misalnya pemanfaatan potensi lingkungan sebagai sumber bahan praktikum. Perlu ada perubahan paradigma dalam pembelajaran IPA; 3) Bagi pihak pemerintah (terkait), disarankan bahwa perlu dilakukan rekrutmen tenaga laboran untuk ditugaskan di laboratorium IPA SMP.

\section{DAFTAR PUSTAKA}

Badan Standar Nasional Pendidikan (BSNP).2006. Standar Sarana dan Prasarana Sekolah/Madrasah Pendidikan Umum. Jakarta: Badan Standar Nasional Pendidikan.

Borg, W.R. \& Gall, M.D. 1983.Educational Research: An Introduction. London: Longman, Inc.

Dewi, K., Sadia I. W., \& Ristiati, N.P. 2013.Pengembangan Perangkat Pembelajaran IPA Terpadu dengan Setting Inkuiri Terbimbing untuk Meningkatkan Pemahaman Konsep dan Kinerja IImiah Siswa.e-Journal Program Pascasarjana Universitas Pendidikan Ganesha Program Studi Pendidikan IPA, Volume 3, No. 1 (2013), halaman 16-28.

Dian, P., Nurlina., and Rahmini., Peranan penggunaan KIT IPA
(Fisika) terhadap hasil belajar fisika siswa MA Muallimin Muhammadiyah Makassar, Jurnal Pendidikan Fisika Unismuh (JPF), vol. 2 no.22013, pp 26-30.

Koretsky, M.D, Christine, K., \& Gummer, E. 2011. Student Perceptions of Learning in theLaboratory: Comparison of IndustriallySituated Virtual Laboratories to CapstonePhysical Laboratories. Journal of Engineering Education. July 2011, Vol. 100, No. 3, pp. 540-573. $\quad$ http://www.jee.org: diakses tgl. 2 Setember 2012.

Munandar. 2008. Pembelajarn IPA Di Sekolah Menengah Pertama Bandung: Alfabeta.

Novianti, N. R. 2011. Kontribusi Pengelolaan Laboratorium dan Motivasi Belajar Siswa terhadap Efektifitas Proses Pembelajaran.Jurnal.Upi.Edu/File/ 15. Edisi Khusus No. 1, Agustus 2011. ISSN 1412-565X. (Online).1.

(https://www.google.com/search?q $=$ Jurnal.Upi.Edu, diakses 6 Juli 2013)

Rahayu, P. Mulyani, S. Miswadi, S.S. 2012.Pengembangan

Pembelajaran IPA Terpadu dengan Menggunanakan Pembelajaran Problem Base Melalui Lesson Study.Jurnal Pendidikan IPA Indonesia (Online) 1(1) (2012) 63-70. (http://journal.unnes.ac.id/index.ph p/ipii, diakses 14 September 2014).

Subamia, I.D.P, Sukatra, I.N, Sastrawidana, I.D.K. 2012 .Pelatihan Keterampilan Dasar Laboratorium (Basic Skill Laboratory) Bagi Staf Laboraorium IPA SMP Se-Kabupaten Buleleng.Jurnal Pengabdian Kepada Masyarakat Widya Laksana. Edisi Juli. 2012. Halaman 38.

Sugiyono, 2010.Metode Penelitian Pendidikan (Pendidikan Kuantitatif, Penelitian Kualitatif, dan R\&D).Bandung: Penerbit Alfabeta. 
Suharningrum, T. 2010. Meningkatkan Kualitas Proses Pembelajaran IPA Siswa Kelas V SDN No. 65/I Tiang Tunggang dengan Menggunakan Alat Peraga Kit IPA.(Online).http://ebookbrowse.c om/45-tatik-suharningrum-coverproposal1doc-d243360024, diakses 2 Juni 2014) 